\title{
THE APPLICATION OF BEHAVIOR THERAPY MODEL FOR THE IMPROVEMENT OF SPEAKING ABILITY OF DYSARTHRIA PATIENTS
}

\author{
Gusdi Sastra ${ }^{1}$, Amel Yanis ${ }^{2}$, Ike Revilta ${ }^{1}$, Handoko ${ }^{1}$ \\ ${ }^{1}$ Faculty of Cultural Sciences, Andalas University, Padang, West Sumatra \\ ${ }^{2}$ Faculty of Medicine, Andalas University, Padang, West Sumatra \\ Email: sastrabudaya84@gmail.com
}

\begin{abstract}
Research on behavior therapy has been conducted on patients with dysarthria, a disorder of articulation due to impairment of the central nervous system, which directly controls the activity of the muscles that play a role in the process of articulation in the pronunciation production. This study discusses three issues: lingual form made by people with dysarthria before getting behavior therapy, emotional influences on lexical and semantic knowledge of the patient, and the achievement of the model of behavior therapy applied to patients with dysarthria speech impairment. The theory used in this study was from Prins (2004) and the method of analysis applied is the method from Nunan (1992)combined with Sudaryanto (1993). The research found that there is an increased ability of patient to talk: nearly 40 percent of the index lingual knowledge or information, 20 percent of semantics, and 40 percent of feeling. Lingual index is significant as a means of therapy for patients with dysarthria. An increase in the speech ability improves confidence in facing social life.
\end{abstract}

Keywords: dysarthria, linguistic therapy, lingual index.

\section{INTRODUCTION}

To use a verbal language, every human is equipped with the ability to speak. Each individual, however, has different ability; many of them are normal but few of them are not. Those who are unable to speak normally can be easily found in society, such as people suffering from dysarthria. The damage is probably located in the part of language nerve in the brain due to a problem in the articulation devices, or because of mental stress which makes one's lose the linguistic ability, or have trouble in cortical motor.

Researches on cortical motoric disorder, especially for patients of spoken language and conversation, has been conducted not only by neurologists but also by neurolinguists during the last few years particularly since the emergence of neurolinguistics in Indonesia. For example, Suhardiyanto (1994) conducted a research on the aspect of language to the patient of language disorder. It discusses the segmental syndrome of a Broca aphasia patient. This research proved that linguist can give contribution to neurological science, especially in looking at the linguistic aspect of language disorder patient. In addition, Sastra (2005) conducted a research on language disorder in aphasia patients from Minangkabau. Sastra (2007) also conducted a research on language disorder of aphasia patients regarding language therapy which can be used to improve their speaking ability.

Dysarthria, an articulation disorder, is one of many speaking disorders. Travis (1971) defines dysarthria as an articulation disorder which is 
caused by damage in the central nervous system, which directly controls the activities of muscles that have a role in the articulation process and production of the sound of utterances. The loss of control from these muscles can be understood as a weakness, delay or non-coordination. This speaking disorder shows troubles in executing the speaking motoric forms which leads to a paralysis, weakness, or disorder in organizing speaking muscles.

Patients with dysarthria have no difficulties in understanding an utterance, reading and writing. They just have obstacles in producing the utterance. The speaking disability of the dysarthria patients can be caused by the disparity or congenital disorder in a particular part of the tongue which is difficult to move. This disorder of tongue movement causes difficulties in oral language. Dysarthria also occurs because of the trouble of coordination among the respiratory muscles, i.e., the larynx, the pharynx, the palate, the tongue, and the lips. (Evans, 1999:12). In other words, dysarthria is a language disorder where the command and coordination of various motoric types to produce an utterance are disturbed; the cause is by the trouble of articulation in the mouth cavity. The symptoms of dysarthria often appear when someone is having an oral interaction (Sastra, 2011:8).

The research about verbal disorder in dysarthria patient is needed. The application of the behaviour of Therapy Model (hereafter abbreviated as BTM) which has already been designed through the research for language therapy will reveal how dysarthria patients think and express their feelings for the efforts of healing. This therapy model can help the patients in their attempts to heal their speaking ability to communicate with other people. By this research, it is expected that the coordination between the linguist and the neurologist can contribute to treating the problems suffered by language disorder patients, especially dysarthria patients.

Based on the above phenomenon, this research has three objectives. They are (1) to reveal the lingual forms that can be performed by dysarthria patient; (2) to explain the evidence that emotion influences the lexical knowledge and semantic of dysarthria patients; and (3) to figure out the echievement of BTM which is applied to the language disorder of dysarthria patient.

In general, this research is conducted by following some working steps, which include observation and natural approach, directional conversation, BTM application, story comprehension, picture simulation of verbal behaviour, and evaluation of each activity (Nunan, 1992). Those steps are embodied through the method and technique of collecting data, analysing data and reporting analysis results (Sudaryanto, 1992)

The population of this research is the dysarthria patients in M Djamil Hospital, Padang. The specimen of the research are the verbal utterance from four dysarthria patients who show the symptom of language disorder of dysarthria. They are under a two month period of observation and another two month period of therapy aplication in the recovery period. Two of them are undergoing hospitalization, and the other two are undergoing outpatient care. They have around 2-4 BDDE (Boston Diagnostic Dysarthia Examination) scale of severity. They hold at least high school education and and have been staying in Padang for at least ten years.

Two of the four research subjects formerly suffered from broca aphasia with the scale 4 BDAE (Boston Diagnostic Aphasia Examination) degree of severity, two years after having a stroke and suffering from dysarthria in the scale of 3.1. The first subjects experiences the dysarthria since the very beginning because of the disturbances in the central nerve which controls the muscle of speaking devices since the last five years. The second one experiences dysarthria because of having an accident which caused the trouble in her speaking devices with the scale of 2 BDDE.

The utterances from the patient are gained through the standard techniques of question and answer, naming objects, picture story, and retelling. The topic is about daily activity and the history of the disease. The Naming object uses a standard test (Dharmaperwira-Prins, 2004), while the picture telling uses Cookie Theft tool (Obler \& Gjerlow, 1999). The utterances are transcribed and then analyzed. 


\section{THE UTTERANCE LINGUAL FORM OF DYSARTHRIA PATIENT}

Based on the research, there are five lingual forms in the verbal errors of dysarthria patients such as replacement, removal/dismissal, addition, discontinuity and shortening. The comparison of the percentage is $22: 32: 4: 8: 6$. The number of error in removal and replacement signals that the patients experience trouble in the level of phonology coding. According to Kohn (1993), if the patient experiences a trouble in producing phoneme, he will tend to dismiss the sound for reaching the phonetic aspect of an utterance. The comparison of five verbal form can be seen in this following graphic.

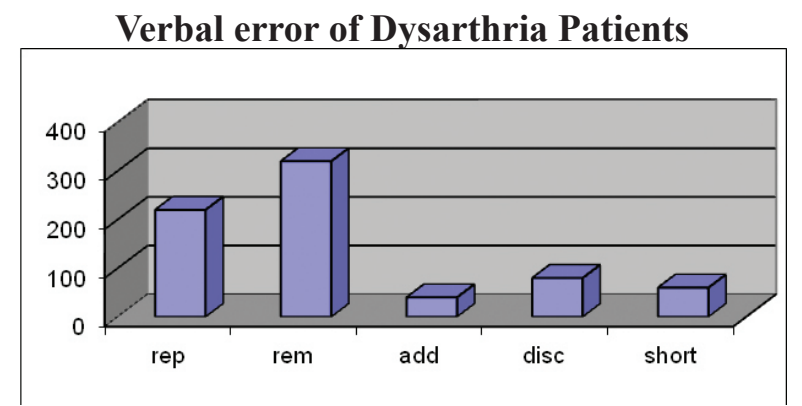

Lingual form: rep $=$ replacement, rem $=$ removal, add $=$ additional, disc $=$ discontinuity, short $=$ shortening. $0-400=$ number of errors

The graphic proves that dysarthria patients often remove the sounds and utilize the previous segment as the strategy to access the intended lexical element by minimizing the additional sound. Replacing the sound is often done because of the lexical skipping which makes the patient reverse the position of the phoneme and words. The lexical shortening is sometimes used for the purpose of speed because the patient tends to be bored in training for the speaking devices and for the repetitive questions.

The following examples show the lingual forms which is phonologically intended. They are obtained prior to the therapy to the research subject.

$\mathrm{R} \quad$ : Gambar seperti ini apa namanya pak? (What picture is it, pak?)

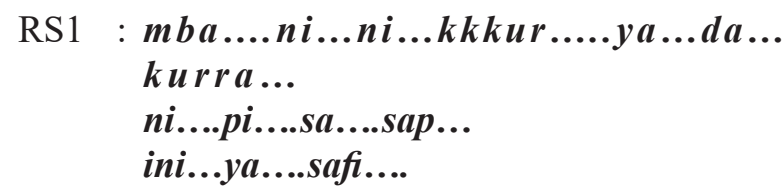

'gambar ini orang mengisap'

(It's a picture of a man smoking.)

$\mathrm{R} \quad$ : Kalau iko apa artinya pak?

'kalau ini apa artinya pak?'

(What about this, pak, what does it mean?)

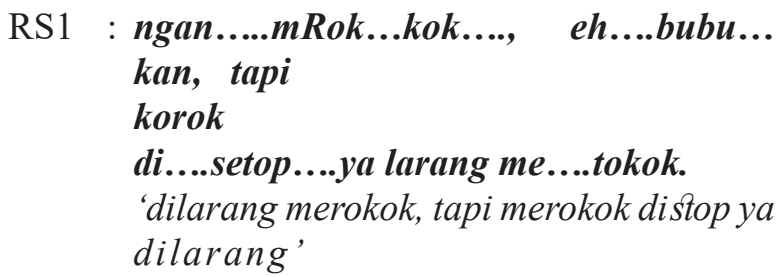

(No smoking, stop smoking, smoking isn't allowed.)

$\mathrm{R} \quad$ : Bapak tinggal dima?

'Bapak tinggal dimana?'

(Where do you live?)

RS1 : tsawa an....kat...(berusaha mengangkat tangan)

'sawahan, dekat'

(Neat the paddy fields.)

$(\mathrm{R}=$ Researcher, $\mathrm{RS}=$ Research Subject $)$

This data exhibits the ability of the dysarthria patient to find the needed lexical element, but because of the damage in the nerves and the muscles which function to produce the sequence of phoneme, the sound of the intended lexicon is changed and inaccurate. RS1 tries several times to produce the accurate phoneme. It implies that dysarthria patient needs a repeated therapy so that the nerve that gives command to the muscles to move the articulation tools can work properly.

Dysarthria patients experiences the disturbance on the left hemisphere, or a certain lesion which causes some troubles in lexicon-semantic element. They have trouble finding words. However, if the words are often used, they can be recognized as a unity with semantic meaning.

\section{Lexical Pronunciation of the Verbal Ability after Therapy}

Dysarthria patients tend to change what they are supposed to read. The change is sometimes semantic. The following sentence is obtained after the therapy. 


$$
\begin{aligned}
& \text { [... paha sodalikñakalaw ibutña } \\
& \text { sudah main kalihatña lucu ...] } \\
& \text {... bahkan sebaliknya, bila keduanya } \\
& \text { sedang bermain kelihatan lucu ... } \\
& \text { (...on the contrary, they're both } \\
& \text { funny when playing...) }
\end{aligned}
$$

The dysarthria patient read the word bila as [kalaw], which is one form of lexical change. This is due to the fact that both words have similar meaning (if). The mind reads [bila], but the pronounced word is [kalaw]. The change of word the patient made is divided into two: 1) still having the same meaning following the change, and 2) having no meaning any more after the change. The following sections provide further elaboration.

\section{Incorrect Pronunciation with Different Meaning:}

The following words go through lexical change and produce different meaning from the intended one (from pictures).

$$
\begin{aligned}
& \text { [...kita lihat sogora moreka hidup } \\
& \text { akaday dan...] } \\
& \text {... kitalihat sekarang, mereka hidup } \\
& \text { sekandang dan ... } \\
& \text { (...we see now, they live in the } \\
& \text { same shed and...) }
\end{aligned}
$$

The patient utters the word sekarang as [sagara] which refers to a different meaning (similar to soon). The error occurs when the patient pronounces the sound $[\mathrm{k}]$ (voiceless) as [g] (voice) and changes the sound [e] as a weak [e]. The patient also omits the [n] at the final syllable of the word. He also makes an error in pronouncing the word sekandang into [əkaday]. Here, the patient omits the sound [s] at the initial position which makes the word meaningless.

\section{(3) [kalaw sivaboluwarga donan kora] kalau singa bersaudara dengan kera.} (If the lion is related to the ape.)

The utterance above shows errors in the pronunciation of two words: 1) singa which is pronounced as [ $\left.\mathrm{si}^{\mathrm{y}} \mathrm{a}\right]$. Here, the sound $[\eta]$ changes to aspirative sound $\left.{ }^{\mathrm{y}}\right]$, which leads to a different meaning; 2) bersaudara which is pronunced as [bəluwarga]. It sounds like berkeluarga. The words bersaudara and berkeluarga have different meanings in Bahasa Indonesian.

$$
\begin{aligned}
& . .[\text {...satelah agak bo rat kaduwa } \\
& \text { sarin dirawa...]. } \\
& \text { setelah agak besar, keduanya } \\
& \text { sering dirawat... } \\
& \text { (...after they got bigger, they were } \\
& \text { often cared for...) }
\end{aligned}
$$

The utterance by the patient shows different meanings from the intended ones. The patient pronounces the word besar as berat. The word besar refers to size (big) while the word berat refers to weight (heavy). Here, two phonemes are changed; the sound [s] is changed to $[\mathrm{r}]$ and sound $[\mathrm{r}]$ at the later position changes to $[\mathrm{t}]$.

$$
\begin{aligned}
& \text { [...kaba bawasan adalah singa itu } \\
& \text { panman bagi...] } \\
& \text {... kera dewasa. Padahal singa itu } \\
& \text { pemakan daging ... } \\
& \text { (... adult ape. Even though the lion } \\
& \text { is a carnivore... ) }
\end{aligned}
$$

The utterance above shows error in pronouncing the word padahal into adalah. The word padahal has different meaning from the word adalah. Here, the patient intended to say padahal, but he uttered adalah. He omitted the sound [p] at the initial position, making the two words look similar in term of the letters. Thus, the error occurs when the patient miss the correct sequence of the letter of the word. The patient switches the sound [h] in the middle position with the sound [1] and pronounces the sound $[\mathrm{h}]$ in the final position. The switch of the sounds results in a new word with different meaning from the intended.

$$
\begin{aligned}
& \text { [... kaday dan yay dipisah pada } \\
& \text { wak tu...] } \\
& \ldots \text { sekandang dan hanya dipisah } \\
& \text { pada waktu ... } \\
& \text { (...in the same shed only they're } \\
& \text { separated by time...) }
\end{aligned}
$$

In data (6), the patients makes mistakes in pronouncing the word sekandang and hanya. The patient misses the initial sound [s] and the middle sound $[\mathrm{n}]$ in the word sekandang. Here, the patient simplifies the word sekandang as [əkaday] which sounds like kadang in Bahasa Indonesia. The 
second error occurs when pronouncing the word hanya into $[y a \eta]$. The patient misses the first syllabe [han] and pronouncing only the later syllable $[y a]$ with an additional sound $[\eta]$, producing the sound like yang $[y a \eta]$ which has different meaning from the word sekandang.

Despite incorrect pronunciation, the words pronounced still have meaning. However, the meaning is different from its real meaning.

\section{Incorrect Pronunciation with No Meaning:}

The following words go through lexical change but produce no meaning at all. For example:

[...sudah kada di kabun dotay Bukittinggi? kita bosa molihat...] ... sebuah kandang di kebun binatang Bukittinggi kita bisa melihat ...

(....a cage in a zoo in Bukittinggi. We can see it...)

In data (7) the patient misses the sounds [n] and $[\eta]$ when pronouncing the word kandang. The patient also makes an error in pronouncing the sound [a] which he pronounce as [ə]. The sound $[k \partial d a]$ has no meaning in Bahasa Indonesia. The word binatang is pronounced as datay which also has no meaning in Bahasa Indonesia. Here, the patient changes the bilabial [b] with alveolar [d] and misses the middle syllable. Moreover, the patient also makes errors in pronouncing the word bisa. He change the sound [i] with [o] which makes the word has no meaning in Bahasa Indonesia.

\section{.. [...singa itu panman bagi da buka mutahi kara...]. \\ singa itu pemakan baging dan bukan mustahil ... \\ (The lion is a carnivore and it's not impossible...)}

The data above shows that the patient makes mistakes in pronouncing the words pemakan and mustahil. In pronouncing the word pemakan, the patient pronounces the word as [panman] which has no meaning. In the word mustahil, the patient misses the sounds [s] and [1] which also has no meaning in Bahasa Indonesia.

$$
\begin{aligned}
& \text { [...lucu akan cadimosañatotapa } \\
& \text { tan ini tida?...] } \\
& \text {... lucu akan menjadi mangsanya. } \\
& \text { Tapi sampai saat ini tidak ... } \\
& \text { (...the cute thing will be its prey. Bu } \\
& \text { now it's not going to happen...) }
\end{aligned}
$$

The data above shows complex errors that include sounds, morphemes, words, and phrases. The word menjadi is pronounced as [cadi]. Here, the patient misses morpheme [men] and pronounces the sound [j] as [c]. The word cadi has no meaning in Bahasa Indonesia. The word mangsa is pronounced as [mosaña] which also has no meaning. The patient omits the sound $[\boldsymbol{y}]$ at the middle of the word. Moreover, the sentence cluster Tapi sampai saat is also mispronounced as [tztapa tan]. Here, the patient makes mistake in pronouncing the word tapi by adding sounds at the initial position (the sounds [to]). The patient also changes the sound [a] with [i] in the final position of the word. The word sampai is absent.

Incorrect pronunciation is frequently made by dysarthria patient and the words pronounced tend to be meaningless.

\section{THE EFFECT OF EMOTION TO THE LEXICAL AND SEMANTIC KNOWLEDGE}

Feelings or emotions, both primary feeling experience (congenital birth) and secondary feeling or emotion, influence the semantic and lexical knowledge of the patient. The whole mental picture is linked each other with certain feelings, while the whole emotion can call the chemistry responses which affect the cognitive process. The meaning of feeling is linked each other with the experience. Thus, by using the picture, the emotions will always be adapted by the patient in understanding various lexical concepts. From a number of lexical data which are asked to the patient, the comparison shows that emotion and knowledge are equal, while the percentage of semantic lexical is quite low. It implies that emotion has a strong effect on the lexical knowledge; the understanding on words 
is still less. The weakness can be improved through the linguistic therapy. The comparison shows 40 percent of lexical knowledge, 20 percent of lexical semantic, and 40 percent of lexical feeling.

\section{Comparison of Knowledge, Emotion, and} Semantic Dysarthria Patient

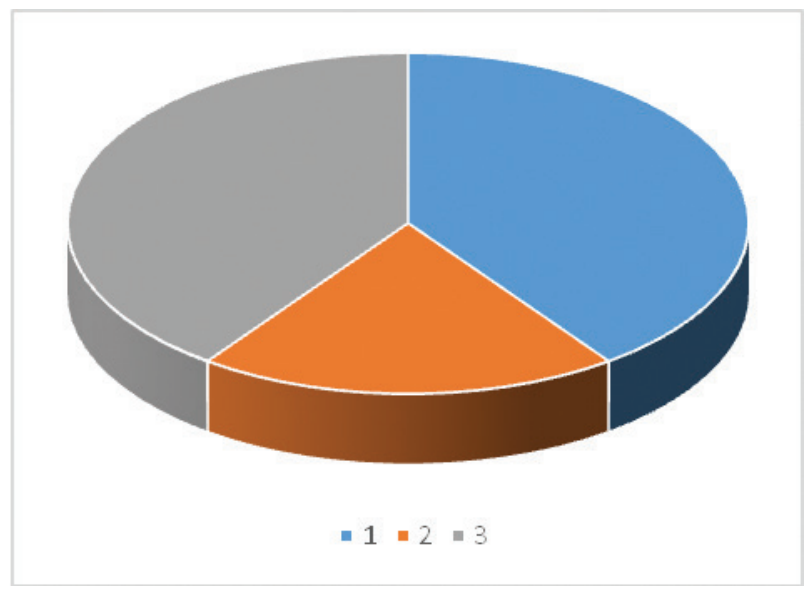

$1=$ knowledge, $2=$ semantic, $3=$ emotion

The following examples show that lexical emotion affects the lexical knowladge and semantic of verbal utterances of dysarthria patients.

$\mathrm{R} \quad$ : Bisa bapak ceritakan gambar ini? (Can you, please, tell me about this picture?)

RS3 : oo ni....anak ko ta...tabuguah... tafi...folici ko....datang sapak... haha...folici kini yapah.....diajek lu baru nyo 'totong.....aden yo cuko eee undak cuko jo folici do.... ici utaknyo fiti ..jo...., aaa liek faja ko ha....kansang na bao honda...... lah? (oo iko, anak ko tabunuah... tapi...polisi ko datang capek...ha.. (polisi kini payah....disogok dulu baru nyo tolong.... aden iyo suko... eh...indak suko jo polisi do....isi utaknyo pitih sajo....aa...lieklah paja ko....kancang bana baok honda......alah?)

'Oo, anak ini terbunuh, tapi polisi datang segera, polisi sekarang susah, suka dibayar, saya tidak suka sama polisi, pikirannya uang saja. Lihatlah orang itu, ngebut sekali bawa motor'.

(Oh, the kid was killed, but the police came very soon, now it's difficult with the police, they like to be bribed, I don't like them, they think about money only. Look at that person, speeding on his bike)

The data shows that the dysarthria patient has the lexical knowledge about the event of the accident. When the researcher asks him in Bahasa Indonesia, he understands what is expected by the researcher, which is to retell a picture the content of which will raise again the emotion of the patient. He understands the lexicons related to police based on his knowledge and experience. Here, the patient is put into an understanding of the lexical concept of a policeman, but the picture shown cannot be retold perfectly. When a Research Subject points to a picture, the patient can re-catch the lexical honda, but does not have an accurate understanding of the words killed and accident.

\section{THE ACHIEVEMENT OF BEHAVIOR THERAPY METHOD OF DYSARTHRIA PATIENT}

Communicating with dysarthria patient during the recovery period as a form of therapy is conducted not only in lingual but also with an audio, vision, and touch. The treatment can be conducted as evaluation. The works follow these processes:

1. Information will be caught from the audio, vision and touch and arrive in the posterior brain

2. A consciousness analysis occurs at the cortical level. The integration keeps going through various stimulus. The semantic knowledge and emotional meaning happen in this case.

3. At the cortical level, the analysis of memory is always integrated from some stimulus of the senses, then the patient will compare it with semantic knowledge.

4. An act will be considered in pre-frontal area and executed as an option. Finally, a thought will be the impulse in running the selective process from various lexical which are kept in brain. 
Therefore, a behavior therapy linked with feeling and emotion is needed to treat the language disorder of dysarthria patients, especially in the recovery period, because it is considered that the function of the right hemisphere is not damaged.

After conducting the linguistic therapy application by giving the patient a two-hour behavior therapy model every two days continuously for two months, there is an improvement of accuracy in phonology and lexicon. In the last month, the patient gains better accuracy of intended meaning based on what is expected by the speech act. This achievement is the evidence that there is an improvement of communicating ability from the dysarthria patients. Out of around 50 speech acts, almost 90 percent of the spelling and words accuracy is improved. The achievement index presented in the following graphic is gained based on the calculation of phonological, lexical, and semantic errors.

\section{The Rising Achievement of Pronunciation and Lexical Accuracy}

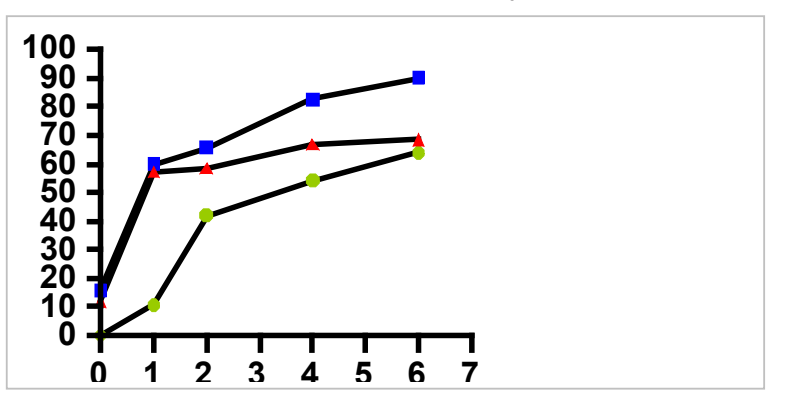

$1-7=$ accuracy of pronunciation (yellow), $0-100=$ number of lexical precision (red and blue).

There is an improvement up until the cortical level and the act chosen to become the selective impulse on the brain. A sharp increase happens in the first and second weeks because of the shock at the five senses, and emotional proximity of the dysarthria patient. Starting from the second week and the sixth week, the utterance shows a stability in terms of both the understanding of knowledge and the understanding toward the repetitive speech act events. The repetition is conducted with the purpose for the phoneme storage and stability between lexical knowledge and understanding.

\section{CONCLUSION}

It can be concluded from the research findings that the dysarthria patients' speaking disorder is an issue of the nerve coordination which generates the muscles with speaking function. The disorder has the severity scale as the effect of the trouble in the work of language nerve on the brain. Dysarthria can be caused by such language disorder as from stroke. Tough it is the first symptom of stroke, dysarthria is not always caused by stroke. It can be caused by an abnormality of their speaking tools which cause the problem of articulation, or the external factor which cause mistakes in using speaking organs causing linguistic disturbance, especially in phonological and lexical aspects.

The highest degree of error is verbal removal. There is an equivalent appearance in the effect of the emotion to the survival of lexical knowledge and lexical feeling, while the understanding on the lexical intended meaning is lower than lexical knowledge and lexical feeling. To improve the communicating ability of dysarthria patients, linguistic therapy using behavior therapy method can be conducted. The application shows an increase of the lingual index, thus, the verbal behavior is much better than before joining the therapy. Through stimulus and the methods applied, it is proven that there is an improvement of lingual ability in the accuracy of phonological, lexical and semantic aspects.

\section{REFERENCES}

Evans, R.W. (1999). Diagnostic Testing in Neurology. Philadelphia: Saunders Company.

Kohn, Susan E. (1993). "Phonological Production Deficits in Aphasia" dalam Phonological Processes and Brain Mechanism, ed. H.A. Whitaker,93-117.NewYork:SpringerVerlag.

Nunan, David. (1992). Research Methods in Language Learning. Cambridge: Cambridge University Press.

Obler K. Oraie dan Kris Gjerlow. (1999). Language and the Brain. Cambrigde: Cambridge University Press.

Reni, I. Dharmaperwira-Prins (2004). Gangguangangguan Komunikasi Hemisfer Kanan dan Pemeriksaan Komunikasi Hemisfer Kanan (PKHK). Jakarta: Djambatan. 
Sastra, Gusdi. (2005). "Ekspresi Verbal Penderita Strok dari Sudut Analisis Neurolinguistik". Disertasi. Kuala Lumpur: Universiti Putra Malaysia.

Sastra, Gusdi. (2007). “Gangguan Berbahasa Penderita Afasia”. Laporan Penelitian. Padang: Universitas Andalas.

Sastra, Gusdi. (2011). Neurolinguistik: Suatu Pengantar. Bandung: Alfabeta

Subyantoro. (2007). "Model Bercerita untuk Meningkatkan Kecerdasan Anak: Aplikasi
Ancangan Psikolinguistik"Journal Humaniora Volume 19. No.3. Yogyakarta: Fakultas Ilmu Budaya UGM.

Sudaryanto. (1992). Metode Linguistik. Yogyakarta: Gadjah Mada University Press.

Suhardiyanto, Totok. (1994). "Bahasa dan Saraf Pusat". Makalah dalam Kongres Linguistik Nasional MLI, Palembang, 1 - 5 Juni 1994.

Travis, L.E. (1971). Handbook of Speech Patology and Audiology. New York: Appleton Century. 